Killing Poetry 



\title{
Killing Poetry
}

\section{Blackness and the Making of Slam and Spoken Word Communities}

\author{
JAVON JOHNSON
}

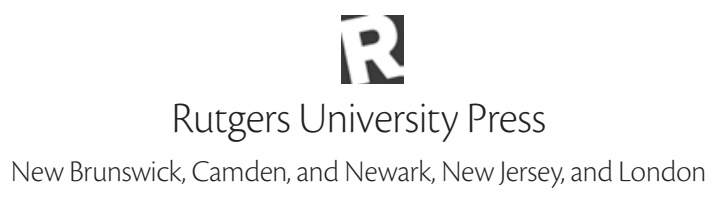




$$
\begin{aligned}
& \text { 978-0-8r } 35-800 \mathrm{I}-2 \text { (pbk.) } \\
& \text { 978-0-8135-8002-9 (hardback) } \\
& \text { 978-o-8135-8003-6 (e-book (epub)) } \\
& \text { 978-o-8135-8004-3 (e-book (web pdf)) }
\end{aligned}
$$

Cataloging-in-Publication data is available from the Library of Congress.

A British Cataloging-in-Publication record for this book is available from the British Library.

Copyright (C) 2017 by Javon Johnson

All rights reserved

No part of this book may be reproduced or utilized in any form or by any means, electronic or mechanical, or by any information storage and retrieval system, without written permission from the publisher. Please contact Rutgers University Press, Io6 Somerset Street, New Brunswick, NJ 0890I. The only exception to this prohibition is "fair use" as defined by U.S. copyright law.

$\infty$ The paper used in this publication meets the requirements of the American National Standard for Information Sciences-Permanence of Paper for Printed Library Materials, ANSI Z39.48-1992.

www.rutgersuniversitypress.org

Manufactured in the United States of America 
For my mother, Valerie Cannon-Mijares. I am because you are. 
